\title{
Entrepreneurial Intention of a Senegalese Entrepreneur in a Brotherhood Context: Towards The Emergence of New "Atypical" Entrepreneurs
}

\author{
Mohammed Said Hammouchi \\ $\mathrm{PhD}$ student at University Ibn TOFAIL, Kenitra, Morocco
}

Doi: 10.19044/esj.2018.v14n7p139 URL:http://dx.doi.org/10.19044/esj.2018.v14n7p139

\begin{abstract}
The purpose of this article is to understand the starting point of the intention of religious entrepreneurs, that we call "Atypical", for the simple reason that their entrepreneurial intentions include not only the economic aspect but there is also evidence of some foundation walls spiritual view of the context in which operate these entrepreneurs: the Tijanie brotherhood. These religious entrepreneurs create travel agencies specializing in the phenomenon of the "Zyara"1. To do this, we will focus initially on generalities about highlighted Islam in Africa, and then we will introduce our paper on the emergence of the Tijaniyya brotherhood. In a second step, we will emphasize the economic dimension of the Tijaniyya, which includes both the phenomenon of the «Zyara», and trade which can arise; but also the emergence of atypical entrepreneurs in their entrepreneurial intentions through creative type travel "Zyara". Our epistemological positioning is interpretative; that is, we go from the field to interpret the intentions of these entrepreneurs, given the absence of literature dealing with entrepreneurship in a religious context. This means that our mode of reasoning is inductive; what brought us to do indepth interviews with this type of entrepreneurs in Senegal. This article presents concrete results concerning the entrepreneurial intentions of the religious entrepreneurs object of our present study. These intentions are religious orders, in the context of these entrepreneurs; on a categorized these intentions under five major axes; "Love and Propaganda of the Brotherhood ; Join the useful to the pleasant ; Respect and love of members of the brotherhood ; Self-achievement ; Tribal or family affiliation ».
\end{abstract}

Keywords: Entrepreneur - Intention - Tijaniyya - spirituality - Zyara

\footnotetext{
${ }^{1}$ Individual or collective visit, on the tomb of a saint or with his living representatives, by people in search of baraka, to ask them for favors or to thank them for wishes granted "(Meriboute, 2010) p. 262.
} 


\section{Introduction}

The development of the entrepreneurial spirit, creativity and innovation represents a major stake of the economic growth especially for the developing countries. All economic actors encourage the promotion of entrepreneurship given its importance to evolve the liberal economic system as well as to stimulate the economic activity of a country.

If a country wants to be competitive, it must ensure that a large number of its population is aware of the entrepreneurial spirit. The latter is considered as the determining factor for the creation of businesses, jobs, increased competitiveness and the restructuring of the economic fabric as well as the fight against poverty.

The entrepreneur is an indispensable player in the socio-economic development that contributes to innovation and the implementation of new strategies. He is considered as an individual with distinct qualities (an innovative, creative and opportunistic person who likes to challenges and take risks).

Academic research in the field of entrepreneurship is progressing fast, especially in Anglo-Saxon countries. Numerous studies have focused on explaining the entrepreneurial phenomenon, through the identification of factors predicting the entrepreneurial act or through the explanation of the processual approaches of the entrepreneurial phenomenon (identification of opportunity, organizational emergence, vision entrepreneurship, project to undertake, etc.).

In this respect, and given its mediating nature between the exogenous variables and the act of creation, the intentional phase of the entrepreneurial process deserves more attention. Indeed, studying the intention in an entrepreneurial perspective seems a good research strategy.

Virtually all researchers interested in business creation agree that intention is an important element in the entrepreneurial process. Thus, (Kolvereid, 1996; N. F. Krueger, Reilly, \& Carsrud, 2000; Tounes, 2003) all state that business creation is an intentional process. Moreover, (J. N. F. Krueger \& Carsrud, 1993) state that the study of a future entrepreneurial behavior is inseparable from the intention that animates the individual as to the manifestation of this behavior.

On the other hand, we note that Entrepreneurial Intentions are influenced by the attitudes, values and beliefs of the individual (J. N. F. Krueger \& Carsrud, 1993; N. F. Krueger et al., 2000). In this sense, the intention may be the best preacher of action regarding the entrepreneurial approach in a specific context. Such as entrepreneurship in a religious context as we present in this paper. 


\section{Theories of entrepreneur intention:}

Academic research in the field of entrepreneurship is interested in explaining this phenomenon, through the explanation of entrepreneurial process approaches (opportunity identification, organizational emergence, entrepreneurial vision, entrepreneurial project, etc.) or through the identification of the predictors of the act of doing business.

For this purpose, many studies postulate that entrepreneurial intent is the almost absolute predictor and the most reliable variable for explaining entrepreneurial behavior (Achour, 2016; Amari, Abbes, \& Boudabbous, 2014; Emin, 2004; Liñán \& Fayolle, 2015; Moreau \& Nantes, 2006; Tounes, 2003; Van, Fred, \& Paul, 2006). In addition, the understanding of the concept of "intent" is based primarily on the contributions of the school of social psychology and the contributions of entrepreneurial research to predict entrepreneurial behavior.

All researchers who question the intentional behavior take into account the cognitive aspects of the individual. From this reflection, two main models of social psychology have emerged in the literature of entrepreneurship: The model of reasoned action (Ajzen \& Fishbein, 1980) and the model of planned behavior (Ajzen, 1991).

The theory of reasoned action (Ajzen \& Fishbein, 1980) states that intention is determined by a person's attitude towards behavior and the importance they attach to opinion and reactions. Of his close entourage as to the adoption of the said behavior. Inspired by this theory, Ajzen, (1991) extended the latter, adding a complementary variable: perceived behavioral control.

In other words, the theory of planned behavior constitutes the extension of the theory of reasoned action, proposed by Ajzen \& Fishbein, (1980). This theory interest to explain that not all behaviors are completely control of volition but the degree of knowledge and control that each individual possesses of his abilities in addition to the resources seem necessary to trigger the desired behavior.

For the author, intention is the intensity with which an individual is willing to try, the level of effort he expects to invest to adopt a behavior (Ajzen, 1991). Thus, the more the intention to adopt a behavior is strong; more the latter does not have to be concretized. Behavioral theory postulates that intention predicts behavior through three variables (Bash, 2015; Crant, 1996; Hermans, Vanderstraeten, Dejardin, Ramdani, \& Van, 2013) :

- Attitude (psychological factors): This is the assessment made by the individual of the desired or intended behavior. They vary according to the results and anticipated consequences of the behavior in question. 
- Subjective norms (socio-cultural factors): They refer to the social pressure experienced by the individual. For example, they can translate into the aspirations of family and friends about an individual's career choice.

- Behavioral control (contextual factors): It represents the degree of knowledge and control that each individual possesses of his abilities in addition to the resources necessary to trigger the desired behavior. The main novelty of the theory of planned behavior of Ajzen, (1991), compared to the model of reasoned action (Ajzen \& Fishbein, 1980).

Therefore, it seems appropriate to study more closely this phenomenon of entrepreneurial intention, not with the traditional entrepreneur, but this time with an entrepreneur, we call "religious" in a context of brotherhood Tijane.

\section{The Tijaniyya and parallel trade}

Since the last decades, several researchers have been interested in the phenomenon of African migration and its intention. Both Bava \& Picard, (2010), note that religion is often the cause of African migration; nevertheless, these migrants are far from forgetting or even abandoning their practices and cultures; on the contrary, they try to reactivate them to exploit them at best. Thus, these scholars postulate that religion gives birth to new religious figures.

In parallel with the development of this phenomenon in Africa, and more specifically in Senegal, the existence of the Tijaniyya brotherhood in Senegal generates social, political economic repercussions on Morocco (Lanza, 2011; Sambe, 2010; Seck \& Lanza, 2014; Triaud, 2010). In this article, we will focus on some of the economic consequences that emerge in an international context between Morocco-Senegal (Lanza, 2014b).

Indeed (Lanza, 2014b), during his ethnographic work on the Tijaniyya in Morocco and Senegal, shows that there are several Tijanes Senegalese who are organizing to visit the temple of their religious guide Sidi Ahmed Tijani. This phenomenon is called the "Zyara". Thus, faithful Tijani people from all over the world get together and organize to visit the tomb of Saint Sidi Ahmed Tijani; the goal being to purify their souls; "Atazkia", and thus arrive at a state of ecstasy and closeness to God (Balambo \& Houssaini, 2014).

Indeed, in this context of brotherhood Tijane in Senegal, there is a rise of a parallel economy; an economy based on the "Zyara" pilgrims in Morocco. According to (Lanza, 2014a) any phenomenon of "Zyara" is an opportunity not only to visit the holy places of the brotherhood everywhere in Morocco but also to take advantage of the situation in order to trade.

Generally, Senegalese Tijanes move to Morocco during the "Mouloud", literally, the birth of the prophet, and take advantage of the situation to trade of all kinds during the circuit prepared for this trip. In the same context, (Bennafla, 2005) notes that the passage of these pilgrims to holy 
places leads to the creation of new markets and a "religious offer reactivated by new actors: the pilgrim traders".

(Lanza, 2012), has conducted extensive research on the Tijaniyya brotherhood in its tryears oldnational context, and noted that the various actors of this "economic-religious sector" gave birth to new entrepreneurial figures, these companies are form of travel agencies commonly called "Zyara" type travel agency; who organize the pilgrimage to Fez. Nevertheless, these companies were created by entrepreneurs like no other.

The example that stands out in force is the development of "Zyara" in the zaouia of Fez, place of pilgrimage of Tijanes since the late 19th century (Seck and Lanza, 2014). This "Zyara" concept has been taken over by more and more organized travel agencies to better carry out all-inclusive "Zyara packs". In addition to e Fez, a key step in the Zyara, agencies organize visits to Casablanca; shopping city, Rabat, Marrakech, Meknes, Moulay Yacoub; and day by day the agencies innovate and create new steps to make the Zyara less tiring and more entertaining. However, each city represents a stage, and each stage refers to a religious interest related to the Tijaniyya; (the Hassan II mosque and the zaouia Tijaniyya in Casablanca, the Zaouias Tijaniyya of Rabat and Marrakech with the mausoleums of the great Moqadems of the brotherhood, the house of one of these great Moqadems in Meknes ...). Guides working on behalf of agencies are often notables of the brotherhood and play a dual role, religious coaching, and tour guide (Lanza, 2016). This type of tourism is therefore a space for strengthening relations "Morocco-Senegal".

To define these concepts, Lanza to adopt an ethnographic method, which consists of immersing yourself in the middle of the Tijanes, pilgrims, sheikhs, and Moqadem and report as objectively as possible the information, gestures, replicas, images or any other aspect found during immersion. Thus, the objective was to find definitions of Baraka in the person supposed to hold it, to complete the definitions found in the books.

Thus, there is a difference between the sheriffs (descendants of the prophet), the sheikhs (religious masters), and the Moqadem (notables of the brotherhood), but all three do not need documents attesting the authenticity of their affiliation or their religious knowledge; their ancestry is largely sufficient to legitimize their supernatural powers, their weight and their status within the brotherhood. Indeed, in this context of brotherhood Tijane in Senegal, there is a rise of a parallel economy; an economy based on the "Zyara" pilgrims in Morocco. Thus, according to (Lanza, 2014b) any phenomenon of "Zyara" is an opportunity not only to visit the holy places of the brotherhood everywhere in Morocco but also to take advantage of the situation in order to trade.

It is in this perspective that our research aims to study the entrepreneurial intention of the religious entrepreneur who created these travel agencies that organize the "Zyara". 


\section{The exploratory study: methodological approach}

In this point, we specify the methodology used in this research. To our knowledge, few works have targeted the religious dimension of Senegalese entrepreneurs in a context of brotherhood. Therefore, it is the exploratory logic, which makes it possible to construct a theory or new concepts (Rispal, 2002) which seems the most adapted to our theme.

In addition, it seemed appropriate to use flexible methods of data collection. In this respect, the qualitative method has been used because of its efficiency in exploratory research (Charreire \& Huault, 2001; Thiétart, 2007).

Consequently, like several researchers' recommendations (Grenier \& Pauget, 2007; Miles \& Huberman, 2003; Rispal, 2002; Thiétart, 2007), the relevant method of collection used in our approach is maintenance (Bell, 2010; Corbi \& Larivi, 2014; Merriam, 1988; R. K. Yin, 2015). Thus, we conducted 10 semi-structured interviews using an interview guide constructed from the concepts used in this research. We interviewed entrepreneurs creating "Zyara" type travel agencies in Senegal and more precisely in Dakar, the economic and political capital of the country.

In addition, targeted sampling is used. It involves identifying companies that meet specific criteria (Bell, 2010; R. Yin, 2003). (Parissier \& Audet, 2013) states that the cases where there is some specific point to remember should be those that are selected, rather than identifying the "typical" cases. Participants are informed because they have certain experiences and insights related to the research question (Cléret, 2013; Corbin \& Strauss, 2008; Merriam, 1988; Miles \& Huberman, 2003; Wacheux, 1996). Indeed, our people have been looking at Muslim entrepreneurs who want to join the Tijane Brotherhood; this desire to explore specific cases reinforces the relevance of this research approach.

In this research, the criteria for the selection of participants include:

- Being Senegalese;

- Being a Muslim Senegalese;

- To be Senegalese Muslim, Tijane;

As a result of the research approach, the sample size is limited to ten cases. This is consistent with the recommendations (Audet \& d'Amboise, 2001; Eisenhardt \& Santos, 2002). Indeed, (Eisenhardt \& Santos, 2002) suggests that there is no ideal sample room, but that the researcher should explore between four and ten cases. When there are fewer than four, there may not be enough people to create a complex piece of music.

Even though, more than ten cases can result in many deaths, which makes the analysis difficult. (Audet \& d'Amboise, 2001) also warn of a large sample size to ensure that the researcher is not overwhelmed by the donkeys. They limit their study on strategic analysis from small businesses to eight cases. 
It is in this sense that we conducted a wave of 10 semi-structured interviews over a period of two months; between March and April 2017. The sample is made up of 5 women and 5 men, as indicated in the table below. The following table gathers all the information related to the panel's contractors.

Table $\mathrm{n}^{\circ}$ 1: Characteristics of the entrepreneurs interviewed

\begin{tabular}{|c|c|c|c|}
\hline & Gender & Age & Brotherhood \\
\hline Entrepreneur 1 & Male & 58 years old & Islam, Tijaniyya \\
\hline Entrepreneur 2 & Male & 31 years old & Islam, Tijaniyya \\
\hline Entrepreneur 3 & Male & 46 years old & Islam, Tijaniyya \\
\hline Entrepreneur 4 & Female & 41 years old & Islam, Tijaniyya \\
\hline Entrepreneur 5 & Female & 40 years old & Islam, Tijaniyya \\
\hline Entrepreneur 6 & Female & 56 years old & Islam, Tijaniyya \\
\hline Entrepreneur 7 & Female & 45 years old & Islam, Tijaniyya \\
\hline «Entrepreneur 8 $》$ & Female & 48 years old & Islam \\
\hline Entrepreneur 9 & Male & 67 years old & Islam, Tijaniyya \\
\hline Entrepreneur 10 & Male & 65 years old & Islam, Tijaniyya \\
\hline
\end{tabular}

Analysis of the collected data was done using the content analysis technique outlined by (Miles and Huberman, 2003). After each interview, we were able to generate codes (Negura, 2006) from the transcripts of the conversations with the interviewees (Anadón, 2006; Creswell, 1998; Glaser \& Strauss, 1967; Locke, 2001).

\section{Results}

In this part, we try to understand the spiritual motives of the entrepreneurial intention of the "Zyara" travel agency creators, from which we will try to propose a conceptual diagram of the intention of the entrepreneurial intention, proposing new concepts from the qualitative study.

Thus, we can summarize all the themes identified from the interviewees' comments in the following table:

Table 2. Main themes from interviews conducted

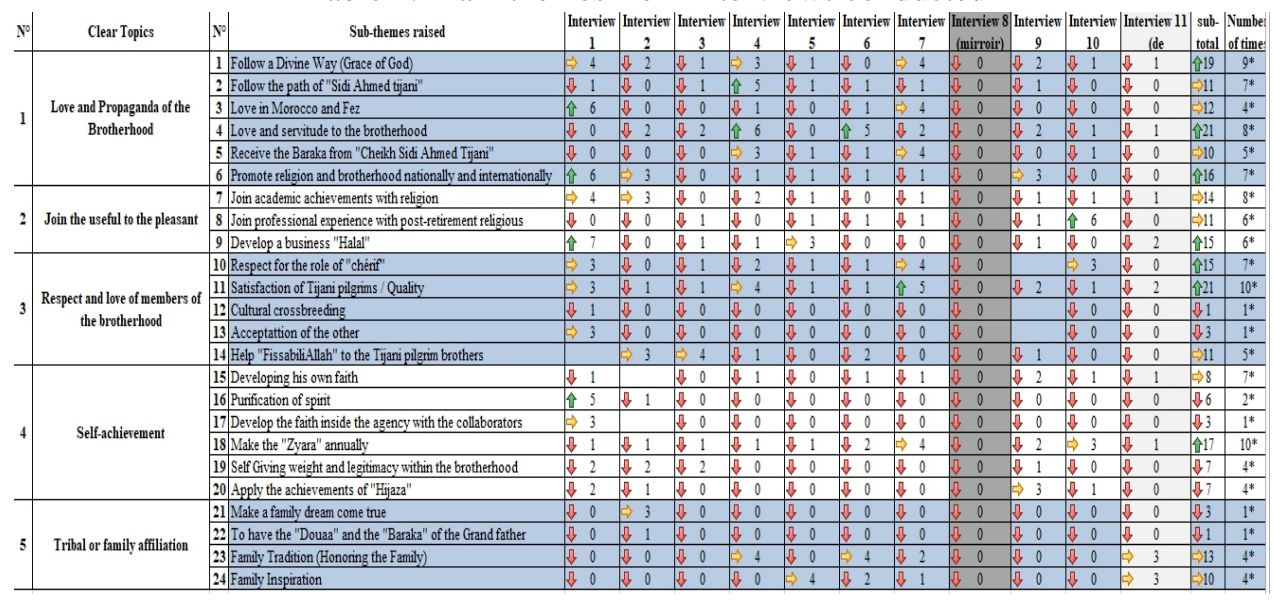

* Number of interviews where the topic was spontaneously mentioned by the interviewee 
Let's begin by summarizing the answers of the interviewees by theme:

First of all, and according to the interviews carried out, we find that all entrepreneurs are Tijanes and consider the brotherhood as an ultimate goal of life; as the interviewee "AS" mentions: "The brotherhood Tijane for me It's the way, my faith, my goal in life and my determination and my intention in all that I do".

\section{- Love and propaganda to the brotherhood: \\ * Follow a divine way:}

The entrepreneurial intent of religious entrepreneurs seems to be motivated by God's motives of seeking God's grace by following his path through the creation of this type of travel agency; as explained by an entrepreneur "MG": "What motivated is that it is a new product of cultural and religious tourism, to promote, to make known to people, also to promote my faith, which is a faith Abrahamic, Islamic, but also my brotherhood Tijaniyya, how to promote and develop it as you saw today in this Sufi Social Forum, it is a way to promote the brotherhood on the economic, spiritual, social and religious "... ... "According to the school of" Elhadj Malick Sy "there are five principles that we follow, there is our religion, our brotherhood (go to Fez), our job, our dahira, and our way (go to Tivaouane ). So as you see visiting Zaouia Sidi Ahmed Tijani is very important for us.

So all of this made me think seriously about what to do; how to develop it; it's actually through a travel agency. And it is with my meager means that I created this agency. ". However, this does not exclude the fact that this entrepreneurial act is motivated by an economic concern; indeed according to "MG", the economic motive "So for me the religious and cultural motives are in perfect harmony and complementarity between them.

In the same way another entrepreneur "NM" underlines to us that what motivated him mainly to initiate an entrepreneurial act of creation of travel agency of the type "Zyara" is the fact to follow his Islamic religious faith: "J ' I created this agency by what simply, it is my faith, it is my objective of life, and it is my religion ".

\section{* Follow the path of Sidi Ahmed Tijani}

Some entrepreneurs like "MCD" have confirmed to us that their entrepreneurial intention is mainly motivated by following a brotherly way of Sidi Ahmed Tijani, the founder of this brotherhood: "As I told you, undertaking in religious tourism, is guided by Allah, It is the way of Sidi Ahmed Tijani that made me enter this sector ........ and I love the tarîqa, and the only way to serve sidi Ahmed Tijani, with what I studied is the creation of travel agency type "Zyara". 


\section{* To receive the Baraka of Sheikh Sidi Ahmed TIJANI}

The interviewees consider that their entrepreneurial intention is motivated by the baraka of their sheikh and spiritual guide; which for them is essential to the success of their business. "I am looking for the total satisfaction of the customer. Motivated by spiritual love throughout the trip, because thanks to the Sheikh's Baraka, we are what we are today. The economic is just for form; we pay the charges and we have a little nothing at all that develops as we have more pilgrims ".

\section{* Promote religion and brotherhood nationally and internationally}

Indeed, one of the reasons for the entrepreneurial intention is the promotion of the Tijani brotherhood at national and international level, moreover the entrepreneur "MG" underlines it in the interview we conducted with him; "What motivated me is that it is a new product of cultural and religious tourism, to promote, to make known to people, also to promote my faith which is an Abrahamic faith, Islamic, but also my Tijaniyya brotherhood, how to promote and develop it as you saw today in this Sufi Social Forum is a way of promoting the brotherhood economically, spiritually, socially and religiously".

\section{- Join the useful to the pleasant \\ * Join academic achievements with religion}

In fact, it appears from the interviews carried out that the entrepreneurial intention of these entrepreneurs was motivated by the fact of joining the academic training to religious concerns; as shown by the entrepreneur "MG": "I attended a training in the hotel and tourism institute of Agadir; here is tourism in General; before I had studied at Karaouiine in Fez. So I was able to join Koranic studies with modern studies. "So it was easier for me to go to religion; so after studying in Agadir; I said to myself that what can go with the training I did in the hotel business that can go with the baggage in religion that I learned in Karaouiine.

An entrepreneur also points out this causality, it is about "AAD", which notes in the interview that: "My studies were purely managerial and my family and religious, and therefore why not join the two. Besides, the prophet was a trader too. There is nothing wrong with making money, the main thing is that it is lawful".

\section{* Develop a Business "Halal"}

Another theme raised during our interviews with these entrepreneurs, that of developing a business called "Halal"; moreover, "MG" mentions it in his speech: "... one bases oneself on the principles of the Tarîqa, they are clear and clear; like what happens in Islamic finance. Last week I participated in a 
symposium on "Halal" cuisine; I made a communication on tourism "Halal", I told them, how there is Islamic finance without there is an Islamic economy; how do you want to finance an illicit economy with legal money; and it was before the Senegalese Minister of Commerce. You need an economy in parallel with Islamic finance, and that's what I did with the creation of this type of travel agency."

"FBA" is an entrepreneur interviewed also about his entrepreneurial intent, he created this agency among other things to promote a business "Halal"; this has been mentioned more than three times in his speech; and I quote for example: "..., because it is the spiritual that regulates the economy and allows us to have a" Halal "economy, so it is a total complementarity".

\section{- Respect and love of members of the brotherhood * Respect of the role of the 'Chérif'}

It appears from interviews with the eleven entrepreneurs that seven of them raised the fact that they created their travel agency just because they were prompted by one of the 'sheriffs' of the zawiya Tijani of Fez . Thus "MG" quotes: "I was one day with the Khalif General of Tijaniyya at the time" Rajab Aziz Sy DABAAX ", hence the name of my agency" Dabaax Asfar ", this is the only agency in Senegal who has a word in Arabic. So I was with the Khalif, in an official delegation invited by King Hassan 2; and every time we were in a hotel, seeing the services, seeing the satisfaction of the people is so important for me, which pushed me to give me funds in this area.

In another interview the interviewee "NM" confirms that: "Once sheriff" Zoubeir "asked me what I was doing now, he asked me to open an agency, and he insisted, after and in 2009, I thought why not do it. And I created my own agency. After when I returned to Morocco, I told him about it, he told me listen Maguette, this agency, is of sheikh sidi ahmed tijani may god have grace on him."

\section{* Satisfaction of Tijane pilgrims}

"MCD" is an entrepreneur who has raised another intention that has pushed him to undertake in this sector; that of the satisfaction of Tijanes pilgrims. He quotes: "I am looking for the total satisfaction of the Customer. Motivated by spiritual love throughout the trip, because thanks to the Sheikh's Baraka, we are what we are today. The economic is just for form; we pay the charges and we have a little nothing at all that develops as we have more pilgrims ".

This was also confirmed by other interviewees; as for example "NM" which emphasizes the importance of the unconditional search for the satisfaction of its pilgrim customers: "So for me it is not for making money, I did it because I am a talibé Tijani, I did it for love. Moreover, in the "Zyara" 
that I organize, I always look for great luxury for my pilgrims while the price is aligned with other competitors. I want all the time to put them at ease. "

- Self-achievement

* Develop his own faith

Indeed, according to the interviews carried out, the theme of development of the entrepreneur's faith is a motive for the entrepreneurial intention in this field. He was quoted Seven Times during the eleven interviews. Thus the entrepreneur "HM" explains that: "I created indeed this travel agency to flourish spiritually and develop my faith whenever it is possible to do the" Zyara".

\section{* Make the "Zyara" Annually}

It is found that there are ten entrepreneurs out of eleven who raised this mobile, which, for them, pushes them to engage in an entrepreneurial act of this kind. "NM" explains to us: "I created this agency to promote the" Zyara "at Sidna Cheikh, but also so that I leave each time to recharge my batteries. With or without the group, I'm leaving. "

\section{- Tribal or family membership \\ * Family Tradition (Honoring Family)}

The interviewee "AAD" raises another theme that is another motive for entrepreneurial intent; that of the family tradition, or the fact of created the travel agency for the simple purpose of honoring the memory of one of the members of the family: "If not for me, I undertook in this sector to realize the dream my brother (may god have his soul) who wanted to help the Tijanes of our tribe in Thies to go to the "Zyara" in Morocco. So that's mainly why, then the tourist area is a bit close to what I had studied. So why not join the two?"

\section{* Inspiration of the family}

Our study also shows that being inspired by one of the entrepreneur's family members is another intention for entrepreneurial intent. The interviewee "FBA" confirms this with his words: "When I went to school in Morocco, I returned to Senegal, and I worked in a travel agency almost 7 or 8 years. After I thought to myself now that I know the job why work with another. I had the idea to create a normal travel agency, and it was my brother who pushed me towards religious tourism; he told me we are Tijani, there are people going to Morocco, why not organize the all-inclusive package and only specialized in that. And in 2006, I started in my own agency."

After having identified the spiritual motives of the entrepreneurial intention most cited by the interviewees, some of the topics that are not 
significant are found. However, cited less than five times, out of the eleven interviews conducted.

\section{Data Analysis: Conceptual Diagram of Entrepreneurial Intent in the Religious Entrepreneur}

After having identified the spiritual motives of the entrepreneurial intention most cited by the interviewees, some of the topics that are not significant are found but cited less than five times out of the eleven interviews conducted.

In fact, we note that the theme most cited by all interviewed remains "Love and propaganda to the brotherhood", and this 89 quotes during the eleven interviews, followed by "Respect and love of the members of the brotherhood "by 51 quotations, then" Self-fulfillment "by 48 citations, then" Joining the useful to the pleasant "by 40 quotations and finally" The tribal or family affiliation "by 27 Quotes.

Regarding the sub-themes raised; it can be seen that out of the eleven interviews carried out, the spiritual motives of the entrepreneurial intention of this type of most-cited entrepreneur are five:

- $\quad$ Follow a Divine way (Grace of God): 9 Times out of 11

- $\quad$ Love and servitude to the brotherhood: 8 Times out of 11

- Join academic achievements with religion: 8 Times out of 11

- $\quad$ Satisfaction of pilgrims Tijanes / Search for quality: 10 Times out of 11

- $\quad$ Perform the "Zyara" Annually: 10 Times out of 11

All these motives are spiritual and shape the entrepreneurial intent of these entrepreneurs. This motivation gives them the status of "atypical", not like a traditional entrepreneur who has an economic concern that pushes him in most cases to undertake.

Therefore, we can conceive the spiritual motives of the entrepreneurial intention in which five major themes coexist.

The following figure summarizes all of these ideas as follows: 
Figure 1: Conceptual diagram of the spiritual intentions of the religious entrepreneurship

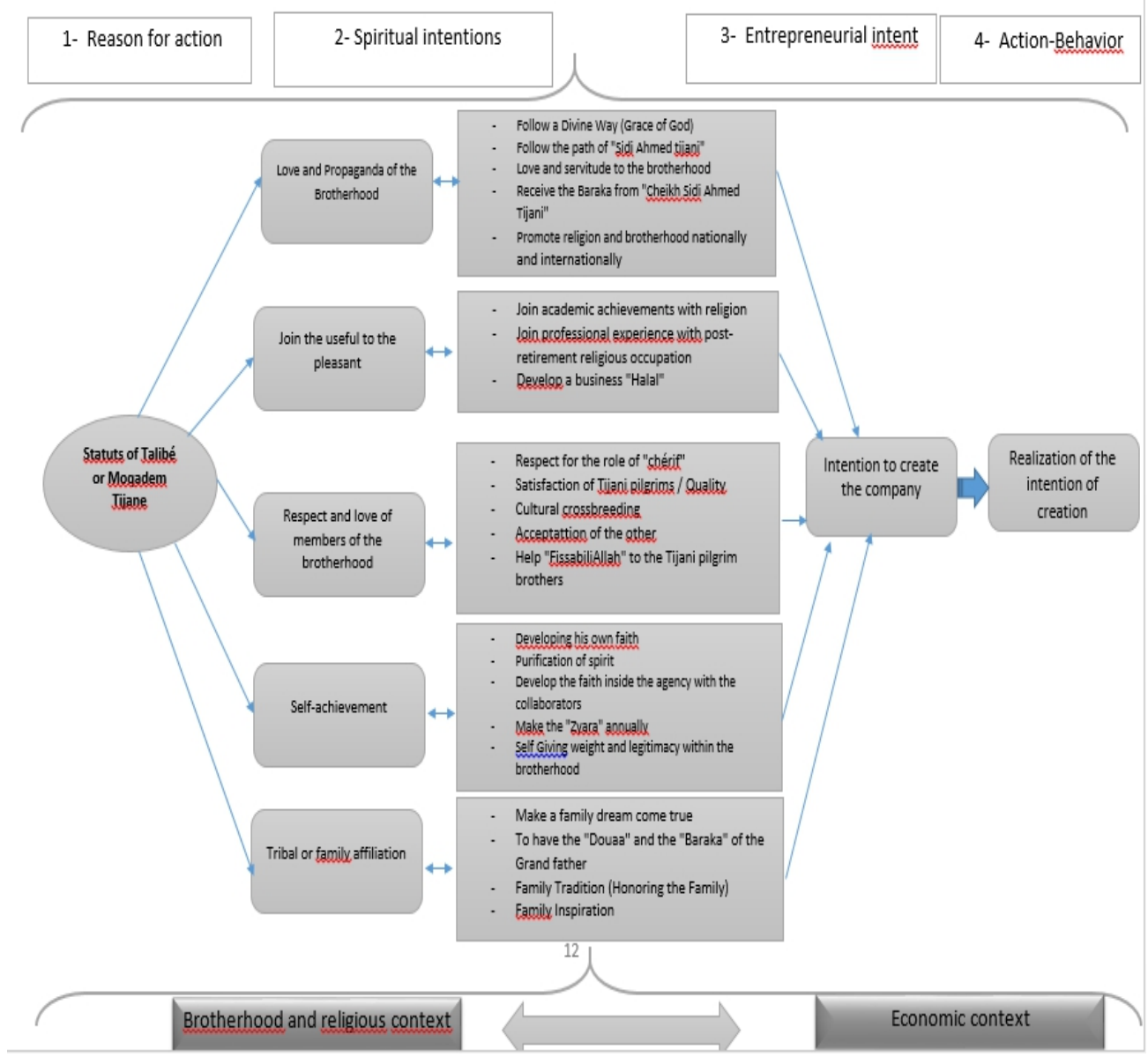

\section{Conclusion}

The creation of companies is a constructive process. Several researches have tried to explain the causes that push the individual to become an entrepreneur.

In this context, a literature research has allowed us to understand that to undertake, it is essential to explain the entrepreneurial intention. Thus, we highlighted a review of literature that allowed us to ask our problem and define the research questions that arise. We thus concentrated on the entrepreneurial intention of the Senegalese religious entrepreneur, and this in a religious context of brotherhood Tijane.

Indeed, in Senegal, there is a system of organization of Zyara in Morocco for the benefit of its members. This led to the creation of certain types of entrepreneurs who created a "Zyara" travel agency. Our study showed us 
that all these entrepreneurs have religious motivations that pushed them to undertake in this context.

In brief, all the actors in this economic-religious sector are straddling between spiritual and entrepreneurial endeavors - the two being confused in a certain sense. Whether one seeks to remove from oblivion his zaouia or to increase the commercial base of his agency, the sense of the action never departed from a certain sense of attachment to his brotherhood. Indeed, this paper leaves a research perspective of the way in which both economic and religious motivations coexist.

\section{References:}

1. Achour, F. Z. (2016). Intention entrepreneuriale des lauréats et facteurs contextuels.

2. Ajzen, I. (1991). The theory of planned behavior. Organizational behavior and human decision processes, 50(2), 179-211.

3. Ajzen, I., \& Fishbein, M. (1980). Understanding attitudes and predicting social behaviour.

4. Amari, F., Abbes, I., \& Boudabbous, S. (2014). L'impact Des Facteurs Environnementaux Sur L'intention Entrepreneuriale.pdf. In International conference on buisiness, economics, Marketing and Management Research (Vol. 2, p. 86-91). Sfax.

5. Anadón, M. (2006). La recherche dite « qualitative » : de la dynamique de son évolution aux acquis indéniables et aux questionnements présents. Recherches qualitatives, 26(1), 5-31.

6. Audet, J., \& d'Amboise, G. (2001). The multi-site study: An innovative research methodology. The Qualitative Report, 6(2), 1-18.

7. Balambo, M. A., \& Houssaini, A. (2014). Les comportements de simplicité volontaire : une lecture à travers la littérature du soufisme en Islam. In La 3 ème édition du Forum International sur la Recherche en Marketing (FIRM-2014).

8. Bash, E. (2015). Entrepreneurship, Religion, and Business Ethics. PhD Proposal, 1(11), 59-69. https://doi.org/10.1017/CBO9781107415324.004

9. Bava, S., \& Picard, J. (2010). Les nouvelles figures religieuses de la migration africaine au Caire. Autrepart, 56, 153-170. https://doi.org/10.3917/autr.056.0153

10. Bell, N. (2010). Qualitative research: good decision making through understanding people, cultures and markets. International Journal of Market Research (Vol. 52). https://doi.org/10.2501/S1470785309201247

11. Bennafla, K. (2005). L'instrumentalisation du pèlerinage à La Mecque à des fins commerciales : l'exemple du Tchad. In Les pélerinages au 
Maghreb et au Moyen-Orient (Presses de, p. 194-202). Damas.

12. Charreire, S., \& Huault, I. (2001). Le constructivisme dans la pratique de recherche: une évaluation à partir de seize thèses de doctorat. Finance Contrôle Stratégie, 4(3), 31-55.

13. Cléret, B. (2013). L'ethnographie comme démarche compréhensive : immersion dans les dynamiques consommatoires du rap en France. Recherches Qualitatives, 32(2), 50-77.

14. Corbi, M., \& Larivi, N. (2014). Methodes qualitatives, quantitatives et mixtes.

15. Corbin, J., \& Strauss, A. (2008). Basics of Qualitative Research: Techniques and Procedures for Developing Grounded Theory. $\begin{array}{llll}\text { Sociologie } & d u & \text { Travail, } & \text { 463-465. }\end{array}$ https://doi.org/10.1016/j.soctra.2016.09.006

16. Crant, J. M. (1996). The proactive personality scale as a predictor of entrepreneurial intentions. Journal of small business management, 34(3), 42.

17. Creswell, J. W. (1998). Quality inquiry and research design: Choosing among five traditions. Thousand Oaks.

18. Eisenhardt, K. M., \& Santos, F. M. (2002). Knowledge-based view: A new theory of strategy. Handbook of strategy and management, 1(1), 139-164.

19. Emin, S. (2004). Les facteurs déterminant la création d'entreprise par les chercheurs publics: Application des modèles d'intention. Revue de l'Entrepreneuriat, 3, 1-20. https://doi.org/10.3917/entre.031.0002

20. Glaser, B., \& Strauss, A. (1967). Grounded theory: The discovery of grounded theory. Sociology The Journal Of The British Sociological Association, 12, 27-49.

21. Grenier, C., \& Pauget, B. (2007). Qu'est-ce que la recherche en management? Recherche en soins infirmiers, 91(4), 12. https://doi.org/10.3917/rsi.091.0012

22. Hermans, J., Vanderstraeten, J., Dejardin, M., Ramdani, D., \& Van, A. (2013). L'entrepreneur ambitieux : état des lieux et perspectives. Revue de l'Entrepreneuriat, 12, 43-70. https://doi.org/10.3917/entre.121.0043

23. Kolvereid, L. (1996). Prediction of employment status choice intentions. Entrepreneurship: Theory and Practice.

24. Krueger, J. N. F., \& Carsrud, A. L. (1993). Entrepreneurship \& Regional Development: An International Entrepreneurial intentions : Applying the theory of planned behaviour. Entrepreneurship \& Regional Development, 5(June 2012), 315-330.

25. Krueger, N. F., Reilly, M. D., \& Carsrud, A. L. (2000). Competing models of entrepreneurial intentions. Journal of Business Venturing, 
15(5-6), 411-432. https://doi.org/10.1016/S0883-9026(98)00033-0

26. Lanza, N. (2011). Liens et Echanges entre le Maroc et l'afrique Subsaharienne. In D'une Afrique à l'autre. (Karthala, p. 21-35).

27. Lanza, N. (2012). Routes et enjeux de la Tijaniyya sénégalaise au Maroc : une zaouïa rbatti sur la voie de Fès (No. 8).

28. Lanza, N. (2014a). Les ponts de spiritualité entre le Maroc et les pays d'Afrique subsaharienne se multiplient.

29. Lanza, N. (2014b). Péleriner faire du commerce et visiter les lieux saints: le tourisme religieux sénégalais au Maroc. L'Année $d u$ Maghreb, 157-171.

30. Lanza, N. (2016). Du Chikh Voyageur au Chikh voyagiste: enjeux et implications d'une transition.

31. Liñán, F., \& Fayolle, A. (2015). A systematic literature review on entrepreneurial intentions: citation, thematic analyses, and research agenda. International Entrepreneurship and Management Journal, 11(4), 907-933. https://doi.org/10.1007/s11365-015-0356-5

32. Locke, K. (2001). Grounded theory in management research. Sage.

33. Merriam, S. B. (1988). Case study research in education: A qualitative approach. Jossey-Bass.

34. Miles, M. B., \& Huberman, A. M. (2003). Analyse des données qualitatives: Recueil de nouvelles méthodes.

35. Moreau, R., \& Nantes, U. De. (2006). Les trajectoires de 1 ' intention entrepreneuriale. Revue internationale P.M.E., 19(418), 101-131.

36. Negura, L. (2006). L'analyse de contenu dans l'étude des représentations sociales. SociologieS, 0-16.

37. Parissier, C., \& Audet, M. (2013). Recherches qualitatives (Vol. 32).

38. Rispal, M. H. (2002). La méthode des Cas : Application à la recherche en Gestion (De Boeck S).

39. Sambe, B. (2010). Tidjaniya: usages diplomatiques d'une confrérie soufie. Politique étrangère, Hiver(4), 843. https://doi.org/10.3917/pe.104.0843

40. Seck, A., \& Lanza, N. (2014). Maroc-Sénégal: une histoire contemporaine entre dynamiques mémorielles et logiques de patrimonialisation. Centre Jaques-Berque, 22.

41. Thiétart, R.-A. (2007). Méthodes de Recherches en Management (3e éd.). Paris: DUNOD.

42. Tounes, A. (2003). L'intention entrepreneuriale: Une recherche comparative entre des étudiants suivant des formations en entrepreneuriat $(b a c+5)$ et des étudiants en DESS CAAE. UNIVERSITE DE ROUEN.

43. Triaud, J.-L. (2010). La Tidjaniya, une confrérie musulmane transnationale. Politique étrangère, 4(Hiver), 831-842. 
https://doi.org/10.3917/pe.104.0831

44. Van, A. howard, Fred, L. F., \& Paul, S. (2006). Entrepreneurial Intentions. Journal of Business Venturing, 11(2), 1-10. https://doi.org/10.1016/j.jbusvent.2010.01.001

45. Wacheux, F. (1996). Méthodes qualitatives et recherche en gestion. Economica.

46. Yin, R. (2003). K.(2003). Case study research: Design and methods. Sage Publications, Inc, 5, 11.

47. Yin, R. K. (2015). Qualitative research from start to finish. Guilford Publications. 